\title{
Distribution of porosity-preserving microquartz coatings in sandstones, Upper Jurassic Danish Central Graben
}

\author{
Margrethe T. Nielsen ${ }^{* 1}$, Rikke Weibel ${ }^{1}$, Jens Therkelsen ${ }^{2}$ and Henrik Friis ${ }^{3}$
}

RESEARCH ARTICLE | OPEN ACCESS

GEUS Bulletin Vol 43 | e2019430103 | Published online: 22 July 2019

https://doi.org/10.34194/GEUSB-201943-01-03

High porosity is a key factor for good reservoir sandstones for both hydrocarbon and geothermal energy exploitation. The porosity of sandstones generally decreases with increased burial depth due to compaction and cementation. However, some sandstones in the North Sea show higher porosity than expected for their burial depth, due to the presence of microquartz coatings (e.g. Aase et al. 1996; Hendry \& Trewin 1995; Jahren \& Ramm 2000; Maast et al. 2011). Siliceous sponge spicules have been documented to be an internal source of silica that promotes microquartz coatings (e.g. Hendry \& Trewin 1995; Aase et al. 1996). Siliceous sponge spicules, the solid 'skeleton' of sponges, consist of opal-A and will dissolve when exposed to higher temperatures, thereby causing supersaturation of the formation water with respect to opal-CT and quartz, resulting in nucleation of numerous small (1-5 $\mu \mathrm{m}$ ) quartz crystals (Williams et al. 1985; Hendry
\& Trewin 1995). To predict reservoir quality it is important to understand the distribution of porosity-preserving microquartz in clastic deposits, and yet this is still poorly understood. To address this, our study presents petrographical analyses of cored sandstone sections from wells of various depositional environments, including back-barrier, estuarine, shoreface and gravity flows, as well as various presentday burial depths across the Danish Central Graben.

\section{Geological background}

The Upper Jurassic sandstones in the Danish Central Graben were deposited as part of the syn-rift sedimentation associated with Late Jurassic rifting of the area. Sedimentation was dominated by mudstones of the Lola and Farsund formations, with local and episodic deposits of intercalated

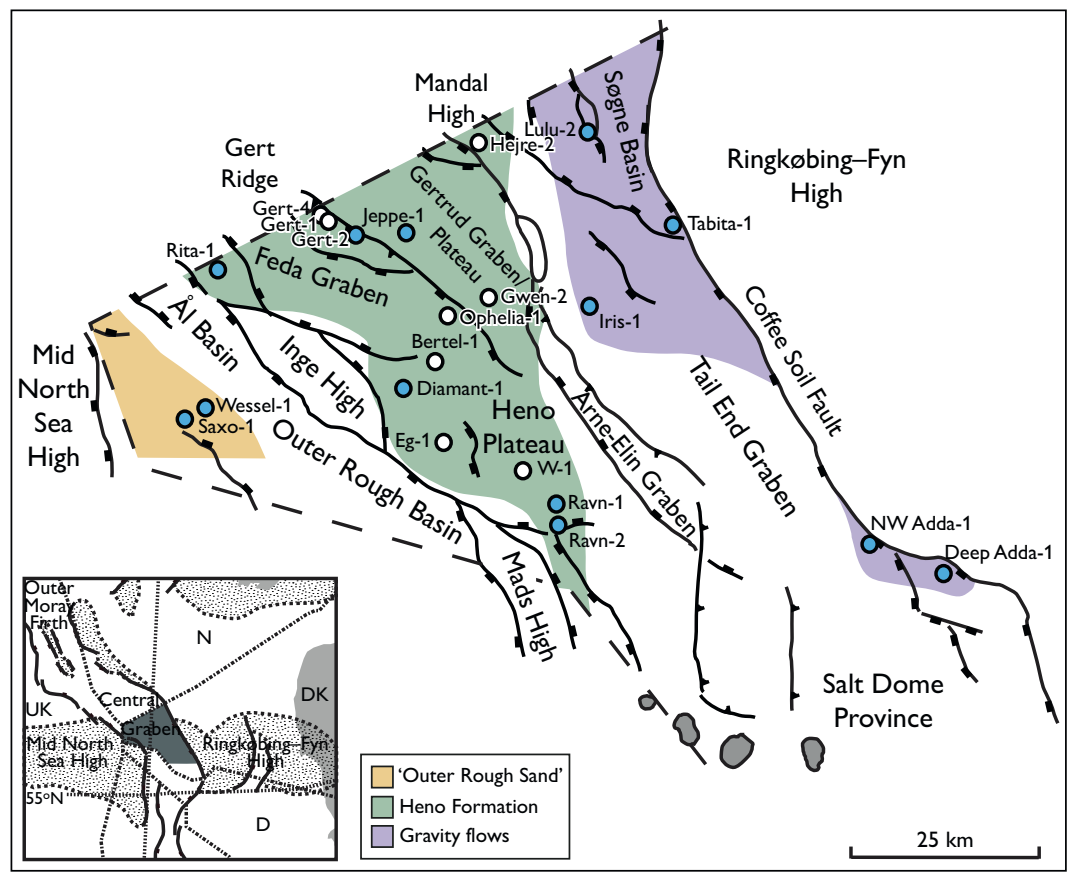

GEUS Bulletin is free to individuals and institutions in electronic form. The author(s) retain copyright over the article contents.

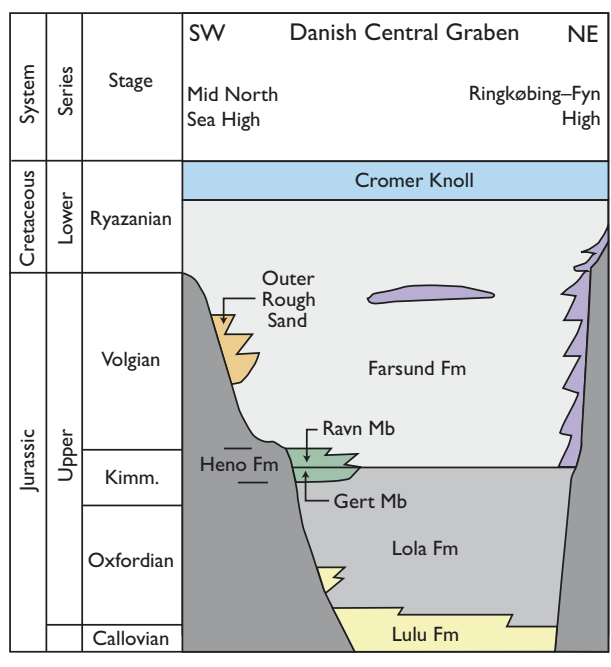

Fig. 1. Part of the Danish sector of the Central Graben showing the 21 sampled wells penetrating Upper Jurassic sandstones. Sandstones with microquartz coatings are indicated by blue dots. Modified from Johannessen (2003). 
sandstones (Andsbjerg \& Dybkjær 2003; Johannessen 2003; Fig. 1). The Heno Formation, deposited between the Lola Formation and the Farsund Formation, is subdivided into the Gert and Ravn members, and is intersected locally by the Lola Formation. The Gert Member consists of mainly estuarine and back-barrier sandstones, while the Ravn Member comprises mainly shoreface sandstones. Both units were deposited in the central part of the Danish Central Graben (Fig. 1). The Farsund Formation sandstones comprise shoreface sandstones deposited along the Mid North Sea High ('Outer Rough Sand' in Fig 1) and deep marine gravity-flow sandstones along the Coffee Soil Fault (Fig. 1). Since deposition, the Upper Jurassic sediments in the Danish North Sea area have been progressively buried to a maximum depth of $5400 \mathrm{~m}$ and temperatures of $160^{\circ} \mathrm{C}$ (Weibel et al.2019).

\section{Methods}

Samples were selected from cores of 21 wells penetrating Upper Jurassic sandstones in the Danish Central Graben (Fig. 1). Plugs were taken perpendicular to the cores, including in one deviated well, and thin sections were made from plug cut-offs. A total of 234 polished thin sections were studied by optical microscopy and by scanning electron microscopy (SEM). The relative mineral abundances are assigned as follows: Dominant (>50\%), abundant (15-50\%), common $(5-15 \%)$, minor $(1-5 \%)$ and rare $(<1 \%)$. Analyses of crystal
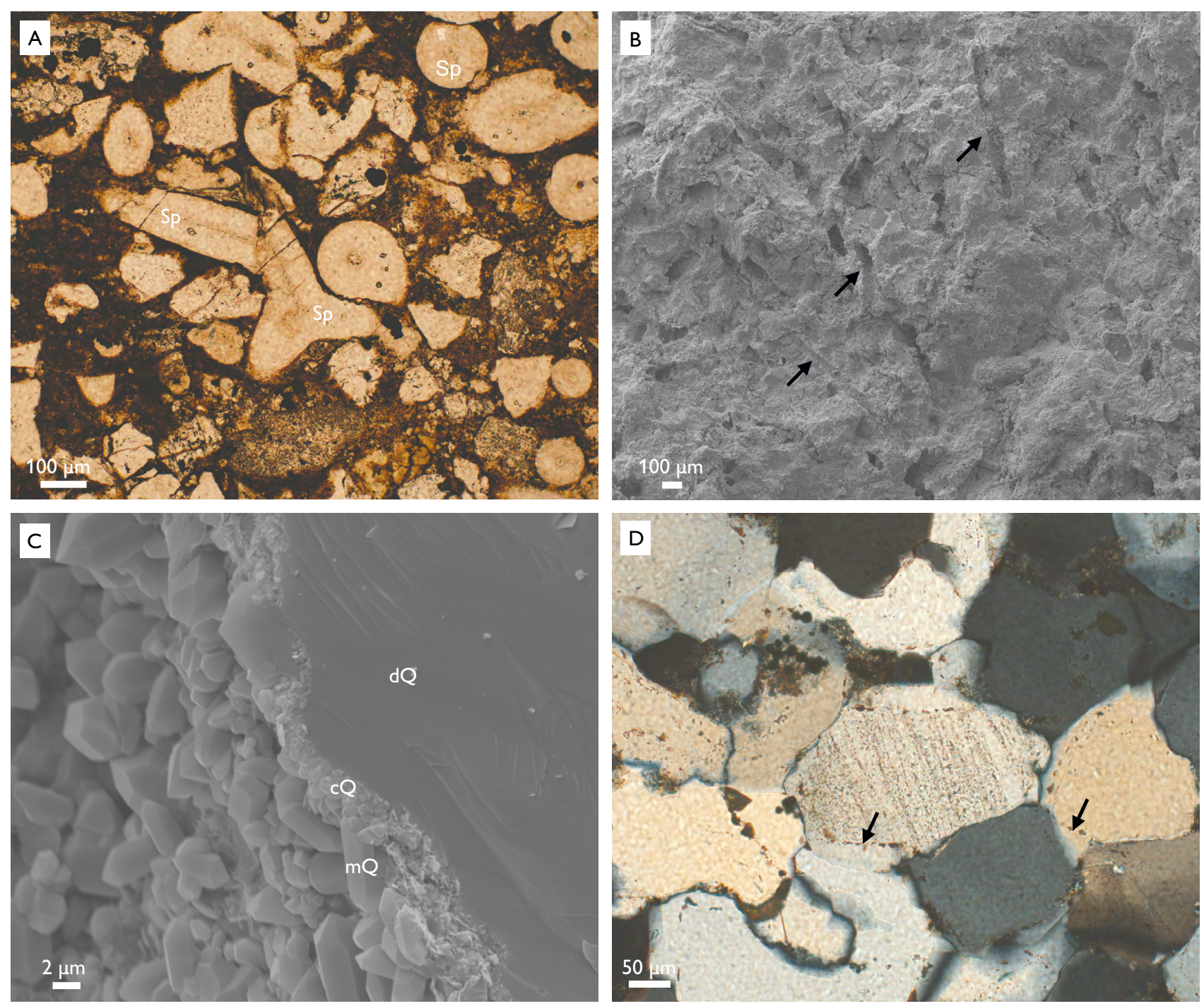

Fig. 2. A: Sand laminae rich in sponge spicules (Sp) preserved in mud-rich facies (Iris-1 well). B: SEM-SE micrograph showing mouldic porosity from the dissolution of siliceous sponge spicules (arrows) with microquartz coatings (Rita-1 well). C: SEM-SE micrograph showing a detrital quartz grain (dQ) coated by cryptocrystalline quartz $(\mathbf{c Q})$, and microquartz $(\mathbf{m} \mathbf{Q}$, Rita-1 well). D: Optical microscopy image under crossed nicols, showing interlocking quartz overgrowths (arrows, Gert-1 well). 
morphologies and paragenetic relationships were performed on gold-coated rock chips by SEM. Relative chemical compositions of mineral phases were obtained using an energy dispersive X-ray spectrometer. Plug porosity and permeability were measured according to the API RP-40 standard (API 1998). Porosity and permeability measurements were performed on sandstones of the Heno Formation and from the 'Outer Rough Sand' of the Farsund Formation, only.

\section{Results}

Detrital composition: In general, quartz grains dominate (>50\%) the detrital composition of the Upper Jurassic sandstones, though some samples contain abundant-dominant (i.e. $>15 \%$ ) calcite shell fragments. Feldspar, comprising both K-feldspar and albite, varies in abundance from rare $(<1 \%)$ to common (5-15\%). Mica rock fragments, organic matter and biogenic particles such as sponge spicules (Fig. 2A) and shell fragments are generally rare or minor $(1-15 \%)$ constituents. Heavy minerals such as rutile, zircon, chromite, apatite, Fe$\mathrm{Ti}$-oxides and tourmaline are rare. Detrital clays are present in varying amounts.

Diagenetic changes: Early diagenetic (eogenesis) cement includes pyrite, sporadic anatase, cryptocrystalline and microcrystalline quartz coatings. The coatings are occasionally associated with mouldic porosity - a form of secondary porosity formed by the dissolution of siliceous sponge spicules. We also observed chlorite coatings in samples with detrital volcanic particles, pores filled by calcite cement in samples with abundant detrital carbonate particles and secondary porosity from the dissolution of feldspar and kaolinite. Later diagenetic (mesogenesis) phases include illite, rare feldspar overgrowths, and dolomite and ankerite overgrowths on detrital carbonate clasts. Also observed were quartz overgrowths, late-patchy calcite cement, rare siderite, barite and sphalerite.

Siliceous authigenic phases: Microcrystalline quartz coatings are observed in a number of wells (Fig. 1). Microquartz typically occurs as a coating on detrital quartz grains (Figs. $2 \mathrm{C}, \mathrm{D})$, and as a coating on detrital carbonate grains in sandstones from the NW Adda-1 well. Cryptocrystalline quartz is observed between the detrital grains and the microquartz coating as shown in Fig. 2 C. Sponge spicules, replaced by the quartz variant chalcedony, and mouldic porosity after dissolved sponge spicules are occasionally present in samples with microquartz coatings (Figs 2A, B). Microcrystalline silica is very abundant and has lithified the sandstones from the Tabita-1 and Deep Adda-1 wells, which contain abundant siliceous sponge spicules. Quartz overgrowths vary in size from discrete incipient overgrowths, which may have started as small outgrowths, to large interlocking quartz cementation as in sandstones from the Gert-1 well (Fig. 2D).

Distribution of microquartz: Stratigraphically, microquartz coatings are restricted to the Farsund Formation and Ravn Member of the Heno Formation, but absent in the Lola Formation and in Gert Member of the Heno Formation (Fig.
Fig. 3. Distribution of microquartz according to $\mathbf{A}$ : lithostratigraphy and $\mathbf{B}$ : depositional environment. Here, offshore environments are represented by the Lola Formation.

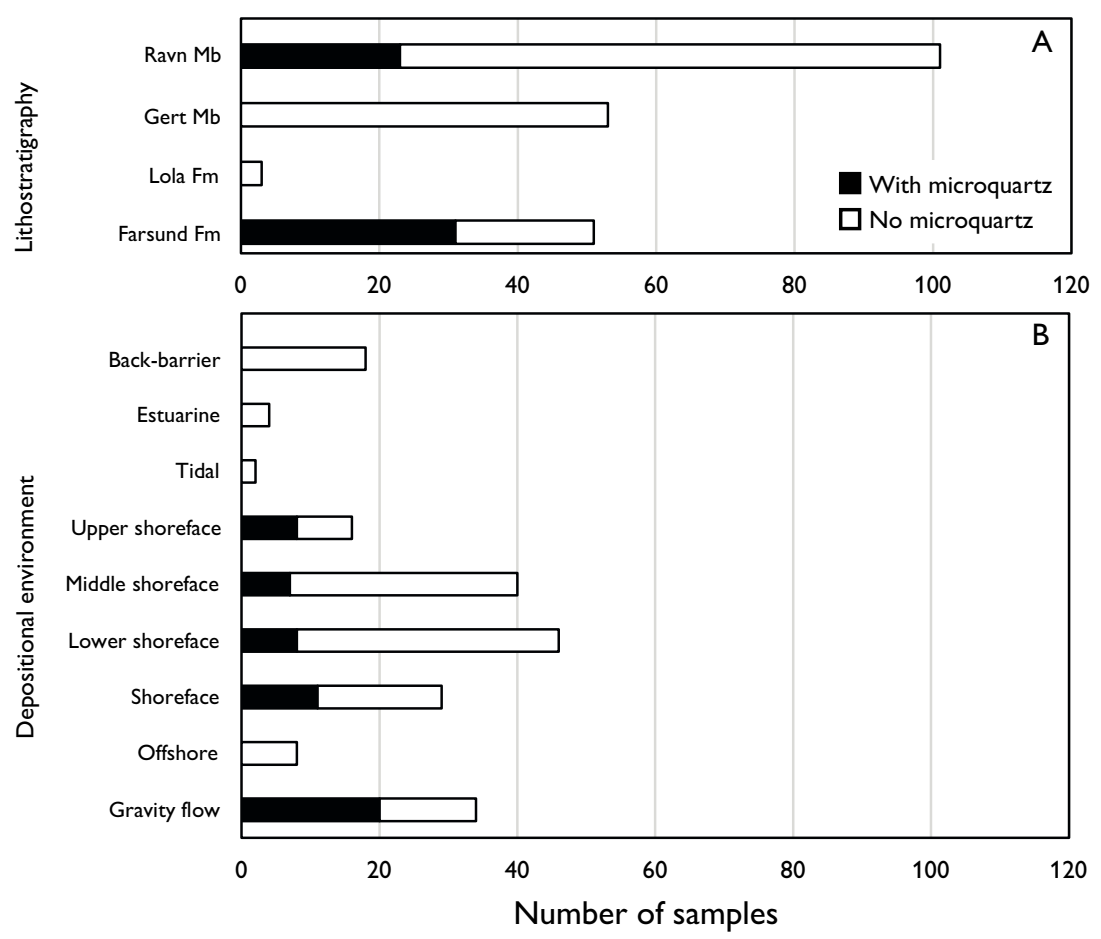


3). Microquartz coatings are restricted to shoreface and gravity-flow sandstones, whereas microquartz coatings are absent in sandstones deposited in back-barrier, estuarine and tidal environments (Fig. 3).

Porosity variation: Sandstones of the Heno Formation generally plot with relatively high porosities when compared to the regional mean porosity-depth trends given by Selley (1978) and Bjørkum et al. (1998) (Fig. 4). Samples with microquartz, shallower than $4.6 \mathrm{~km}$, have overall porosities of $20.7 \% \pm 8.0$, compared with $12.2 \% \pm 5.6$ for samples without microquartz. Many samples deeper than $4.6 \mathrm{~km}$ also show relatively high porosities compared to regional trends, even though microquartz is rarely observed in these sandstone samples (Weibel et al. 2019).

\section{Discussion}

The porosity of the Upper Jurassic sandstones shows large variations at all depths (Fig. 4), though there is a general trend towards lower average porosity at increased depth. Microquartz has a positive influence on porosity preservation in sandstones from depths $\leq 4.6 \mathrm{~km}$, which is the maximum depth of observed microquartz in The Danish Central Garben. This is due to a combination of mechanical stabili-

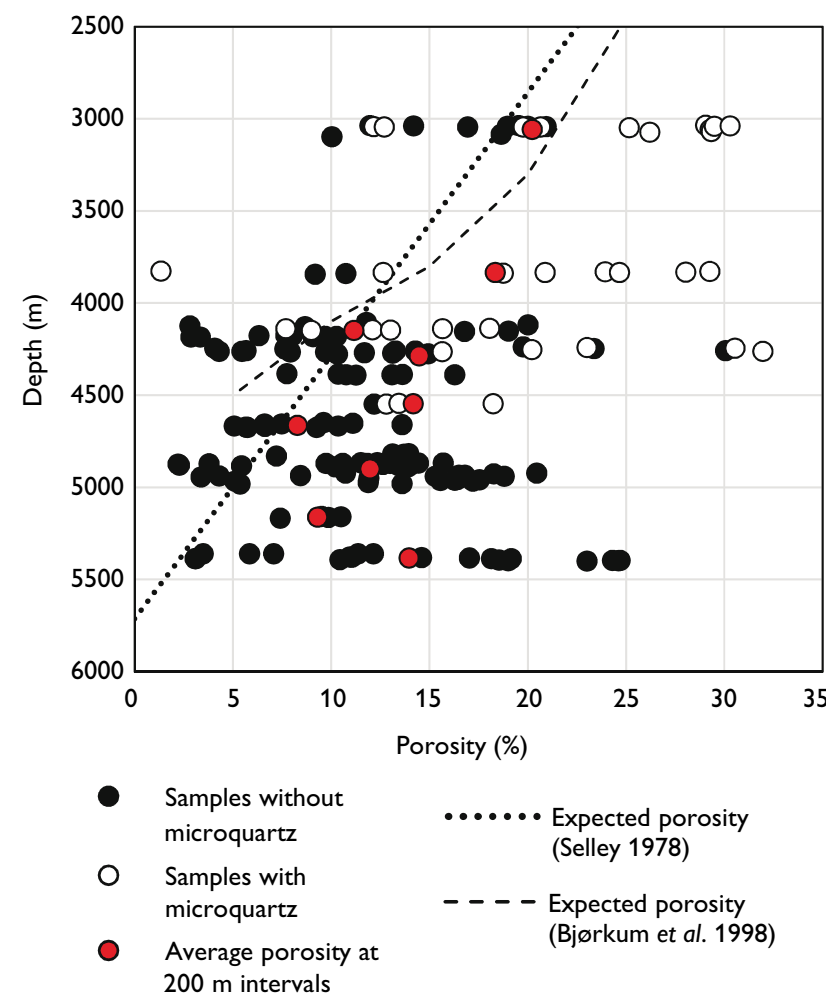

Fig. 4. Porosity vs. depth for samples with (white dots) and without (black bots) microquartz. Also shown are estimated or predicted porosity-depth curves according to Selley (1978) and Bjørkum et al. (1998). sation of the sandstone and inhibition of quartz cementation (Aase et al. 1996; Jahren \& Ramm 2000; Bonnell et al. 2006; Lander $e t$ al. 2008). The porosity-preserving effect of microquartz coatings is particularly pronounced when the individual crystals are randomly orientated. Whereas coatings with a consistent crystallographic orientation can become overgrown by macroquartz (e.g. Weibel et al. 2010; French et al. 2012; French \& Worden 2013).

The presence of microquartz coatings surrounding mouldic porosity after dissolved sponge spicules (Fig. 2B) suggests a close relationship, which is in line with previous studies by Hendry \& Trewin (1995) and Maast et al. (2011), suggesting that microquartz coatings in the North Sea are sourced from dissolved silicous sponge spicules. In the Upper Jurassic sandstones of the Danish Central Graben, microquartz coatings are restricted to sandstones deposited in gravityflow and shoreface environments (Ravn Member and Farsund Formation), while microquartz is absent in sandstones deposited in back-barrier and estuarine environments (Gert Member). This corresponds to the preferred marine habitats of silica sponges (demosponges) during the Late Jurassic (Leinfelder et al. 1996). Demosponges are filter feeding organisms that consume predominantly nanoplankton, which decrease in abundance with depth, and hence, demosponges preferentially occur in shallow marine, middle and outer ramp environments (Leinfelder et al. 1996). As the sponges colonised the sea floor, died and disintegrated, the 'skeletal' spicules, would have been released into the environment. Sponge spicules from the shoreface environments could have been carried to deeper waters along with sand grains by gravity flow, similar to the interpretations of the Cretaceous sandstones in the UK North Sea (Hendry \& Trewin 1995).

Microquartz coatings are only observed in sandstones buried no deeper than than $4.6 \mathrm{~km}$ (Fig. 4), corresponding to maximum temperatures of $c .150^{\circ} \mathrm{C}$ assuming a geothermal gradient of $33^{\circ} \mathrm{C} \mathrm{km}^{-1}$ (Evans 2003). This may be explained by increasing temperatures making larger quartz crystals in continuous overgrowths thermodynamically more stable (Williams et al. 1985). Microcrystalline quartz formed at a low temperature may coarsen during increased burial to form a thermodynamicaly stable crystal, but this thermodynamic drive is less likely to have promoted coarse microquartz crystals $(c .5-10 \mu \mathrm{m})$ to be dissolved and replaced by syntaxial overgrowths (William et al. 1985; Hendry \& Trewin 1995; Jahren \& Ramm 2000). The deeper buried sandstones probably never developed significant amounts of microquartz or other early diagenetic phases, such as opal-CT, or zeolite protected the grain surfaces and were later dissolved during increased burial, thereby exposing the grain surfaces for macroquartz nucleation (e.g. Hendry \& Trewin 1995; Weibel et al. 2010, 2019). 


\section{Conclusions}

Microquartz coatings in Upper Jurassic sandstones of the Danish Central Graben are confined to offshore gravity flows and shoreface sandstones, and absent in sandstones deposited in back-barrier and estuarine environments. In the samples presented here, chalcedonic sponge spicules and mouldic porosity after sponge spicules often coincide with the presence of microquartz coatings. This observation supports the idea that the presence of microquartz is determined by silica sponge habitats and depositional processes. Improved understanding of the depositional environments likely to concentrate siliceous sponge spicules would enable prediction of sandstone reservoirs that contain microquartz coatings and exceptionally high porosity and permability.

\section{Acknowledgments}

This study is based on results from the multiclient project PETSYS to which numerous colleagues at GEUS have contributed. Thanks are addressed to reviewers J. Hendry and J. Jahren for their consructive comments, which improved the paper.

\section{References}

Aase, N.E., Bjorkum, P.A. \& Nadeau, P.H. 1996: The effect of graincoating microquartz on preservation of reservoir porosity. AAPG bulletin 80, 1654-1673. https://doi.org/10.1306/64eda0f0-1724-11d7$8645000102 \mathrm{c} 1865 \mathrm{~d}$

Andsbjerg, J. \& Dybkjær, K. 2003: Sequence stratigraphy of the Jurassic of the Danish Central Graben. Geological Survey of Denmark and Greenland Bulletin 1, 265-300.

API RP 40. 1998: Recommended practices for core analysis, second edition. 236 pp. Washington: American Petroleum Institute.

Bjørkum, P.A., Oelkers, E.H., Nadeau, P.H., Walderhaug, O. \& Murphy, W.M. 1998: Porosity prediction in quartzose sandstones as a function of time, temperature, depth, stylolite frequency, and hydrocarbon saturation. AAPG Bulletin 82, 637-648. https://doi.org/10.1306/1d9bc5cf$172 \mathrm{~d}-11 \mathrm{~d} 7-8645000102 \mathrm{c} 1865 \mathrm{~d}$

Bonnell, L., Larese, R. \& Lander, R. 2006: Porosity preservation by inhibition of quartz cementation: microquartz versus hydrocarbons. AAPG International Conference and Exhibition, Perth, West Australia, 5-6 November, 2006.

Evans, D. 2003: The millennium atlas: Petroleum geology of the central and northern North Sea, 389 pp. London: The Geological Society.

French, M.W. \& Worden, R. 2013: Orientation of microcrystalline quartx in the Fontainebleau Formation, Pris Basin and why it preserves porosity. Sedimentary Geology 284-285, 149-158. https://doi. org/10.1016/j.sedgeo.2012.12.004

French, M.W., Worden, R., Mariani, E., Larese, R.E., Mueller, R.R. \& Kliewer, C.E. 2012. Microcrystalline quartz generation and the preservation of porosity in sandstones: Evidence from the Upper cretaceous of the Subhercynian Basin, Germany. Journal of Sedimentary Research 82, 422-434. https://doi.org/10.2110/jsr.2012.39

Hendry, J.P. \& Trewi, N. 1995: Authigenic quartz microfabrics in Cretaceous turbidites: evidence for silica transformation processes in sandstones. Journal of Sedimentary Research A65, 380-392. https://doi. org/10.1306/d42680cc-2b26-11d7-8648000102c1865d

Jahren, J. \& Ramm, M. 2000: The porosity-preserving effects of microcrystalline quartz coatings in arenitic sandstones: examples from the Norwegian continental shelf. In: Worden, R.H. \& Morad, S. (eds): Quartz cementation in sandstones: Special Publication 29 of the International Association of Sedimentologists Series, 271-280. Blackwell Publishing Ltd. https://doi.org/10.1002/9781444304237.ch18

Johannessen, P.N. 2003: Sedimentology and sequence stratigraphy of paralic and shallow marine Upper Jurassic sandstones in the northern Danish Central Graben. Geological Survey of Denmark and Greenland Bulletin 1,367-402.

Lander, R.H., Larese, R.E. \& Bonnell, L.M. 2008: Toward more accurate quartz cement models: The importance of euhedral versus noneuhedral growth rates. AAPG Bulletin 92, 1537-1563. https://doi. org/10.1306/07160808037

Leinfelder, R.R., Werner, W., Nose, M., Schmid, D.U., Krautter, M., Laternser, R., Takacs, M. \& Hartman, D. 1996: Paleoecology, growth parameters and dynamics of coral, spone and microbolite reefs from the Late Jurassic. In: Reitner, J., Neuweiler, F. \& Gunkel, F. (eds): Global and regional controls on biogeneic sedimentation. I. Reef evolution. Research Reports. Sb2, 227-248. Universität Stuttgart.

Maast, T.E., Jahren, J. \& Bjørlykke, K. 2011: Diagenetic controls on reservoir quality in middle to upper Jurassic sandstones in the South Viking Graben, North Sea. AAPG Bulletin 95, 1937-1958. https://doi. org/10.1306/03071110122

Selley, R.C. 1978: Porosity gradients in North Sea oil-bearing sandstones. Journal of the Geological Society 135, 119-132. https://doi. org/10.1144/gsigs.135.1.0119

Weibel, R., Friis, H., Kazerouni, A.M., Svendsen, J.B., Stokkendahl, J. \& Poulsen, M.L. 2010: Development of early diagenetic silica and quartz morphologies - Examples from the Siri Canyon, Danish North Sea. Sedimentary Geology 228, 151-170. https://doi.org/10.1016/j.sedgeo.2010.04.008

Weibel, R., Olivarius, M., Jakobsen, F.C., Whitehouse, M., Midtgaard, H., Larsen, M. \& Nielsen, K. 2019: Thermogenetic degradation of early zeolite cement: An important process for generating anomalously high porosity and permeability in deeply buried sandstone reservoirs? Marine and Petroleum Geology 103, 620-645. https://doi.org/10.1016/j. marpetgeo.2019.02.006

Williams, L.A., Parks, G.A. \& Crerar, D.A. 1985. Silica diagenesis: I. Solubility controls. Journal of Sedimentary Petrology 55, 301-311. https:// doi.org/10.1016/0198-0254(85)93828-2

\section{How to cite}

Nielsen, M.T., Weibel, R., Therkelsen, J. \& Friis, H. 2019: Distribution of porosity-preserving microquartz coatings in sandstones, Upper Jurassic Danish Central Graben. Geological Survey of Denmark and Greenland Bulletin 43, e2019430103. https://doi.org/10.34194/ GEUSB-201943-01-03

\footnotetext{
*Corresponding author: Margrethe T. Nielsen |E-mail:mtn@geus.dk

${ }^{1}$ Geological Survey of Denmark and Greenland (GEUS), Øster Voldgade 10, DK-1350, Copenhagen K, Denmark.

${ }^{2} \mathrm{MOE}$ A/S, Nestvedvej 1, DK-4760 Vordingborg, Denmark

${ }^{3}$ Department of Geoscience, Aarhus University, Høegh-Guldbergs Gade 2, DK-8000 Aarhus C, Denmark.
} 